\title{
MALAYSIA AND THE ROME STATUTE: THE ISSUE OF SOVEREIGNTY*
}

\author{
Abdul Ghafur Hamid**
}

\begin{abstract}
The announcement of Malaysia's accession to the Rome Statute on March 4, 2019 was met with strong objection by the opposition and some stakeholders. One of the main arguments made by those who opposed the Rome Statute was that "it will, in the end, destroy national sovereignty." Although the argument appears to be political rhetoric, it has already injected confusion among the general public and painted a dark picture that the Rome Statute is a hegemonic law that will rob Malaysia of its sovereignty. The main purpose of the present paper, therefore, is to set the record straight and to prove the simple fact that entering into a treaty is in fact a clear exercise of a State's sovereignty and not to lose sovereignty. Firstly, the paper reappraises the concept of sovereignty: in its original form and its evolution from 16th century to 21 st century, on the basis of State practice, doctrine and judicial pronouncements. Secondly, arguments against the Rome Statute made by some powerful States are analysed and rebutted. Thirdly, Malaysia's situation is objectively evaluated in the light of a comparison between the Rome Statute and other onerous treaties to which Malaysia has already been a party. The paper concludes with the findings that States with their own free will restrict their sovereignty to subject themselves to international law and that Malaysia by no means will lose its sovereignty by acceding to a treaty. Most importantly the Government must prioritize the need to convince the people that it is the right thing to do - it is beneficial to the people of Malaysia or it can achieve the higher aim of protecting humanity.
\end{abstract}

* This paper is funded by a Fundamental Research Grant Scheme (FRGS), granted by the Ministry of Education of Malaysia under the Project ID: FRGS19-132-0741.

** Professor of law and Coordinator of International law and Maritime Affairs (ILMA) Research Cluster, Ahmad Ibrahim Kulliyyah of Laws, International Islamic University Malaysia. Email: at ghafur@iium.edu.my.

[Received: 10 November 2019, Accepted: 25 November 2019, Published: 30 December 2019] 
Keywords: the Rome Statute, the International Criminal Court, Malaysia's accession, the concept of sovereignty

\title{
MALAYSIA DAN STATUT ROM: ISU KEDAULATAN
}

\begin{abstract}
ABSTRAK
Pengumuman penyertaaan Malaysia dalam Statute Rom pada 4 Mac 2019 telah mendapat bantahan kuat oleh pembangkang dan beberapa pihak berkepentingan. Salah satu hujah utama yang dikemukakan oleh pihakpihak yang menentang Statut Rom ialah "pada akhirnya, ia akan memusnahkan kedaulatan negara." Walaupun hujah itu kelihatan retorik politik, ia telah menyuntik kekeliruan di kalangan masyarakat umum dan telah memberikan gambaran bahawa Statut Rom adalah undang-undang hegemoni yang akan merampas kedaulatan Malaysia. Sehubungan dengan itu, artikel ini bertujuan untuk menetapkan rekod lurus dan membuktikan fakta mudah bahawa menyertai suatu perjanjian adalah sebenarnya suatu pelaksanaan yang jelas tentang kedaulatan Negara dan bukannya kehilangan kedaulatan. Pertamanya, artikel ini menilai semula konsep kedaulatan: dalam bentuk asal dan evolusinya dari abad ke-16 hingga abad ke-21, berdasarkan amalan, doktrin dan keputusan kehakiman sesuatu negara. Kedua, hujah terhadap Statut Rom yang dibuat oleh beberapa negara yang berkuasa besar dianalisa dan dibalas. Ketiga, keadaan Malaysia secara objektif dinilai berdasarkan perbandingan antara Statut Rom dan perjanjian lain yang telah disertai oleh Malaysia. Kesimpulannya, hasil kajian ini menunjukkan bahawa Negara-negara dengan kehendak bebas mereka telah menyekat kedaulatan mereka sendiri untuk tertakluk kepada undang-undang antarabangsa dan Malaysia tidak akan kehilangan kedaulatannya dengan hanya menandatangani sesuatu perjanjian. Apa yang paling penting ialah Kerajaan harus mengutamakan keperluan untuk meyakinkan rakyat bahawa ia adalah perkara yang betul untuk dilakukan - ini memberi manfaat kepada rakyat Malaysia atau ia boleh mencapai matlamat yang lebih tinggi dalam melindungi kemanusiaan.
\end{abstract}

Kata Kunci: Statut Rom, Mahkamah Jenayah Antarabangsa, penyertaan Malaysia, konsep kedaulatan 


\title{
INTRODUCTION
}

The Minister of Foreign Affairs, Dato' Saifuddin Abdullah, signed the Instrument of Accession to the Rome Statute of the International Criminal Court (ICC) ${ }^{1}$ on 4 March 2019. The instrument was deposited with the Secretary-General of the United Nations on the same day. ${ }^{2}$ The Secretariat of the United Nations issued the Depository Notification, stating that "the Statute will enter into force for Malaysia on 1 June 2019 in accordance with article 126(2) of the Rome Statute."3

However, the Foreign Minister's announcement that Malaysia has acceded to the Rome Statute has ignited uproar about its effects on sovereignty and royal immunity. Opposition parties and interest groups, with the support of certain royalties, vehemently moved against the accession to the Rome Statute. The opening attack was launched by certain members of royalty, who raised the objection that the accession would expose Yang di Pertuan Agong to prosecution before the ICC and it was unconstitutional as Conference of Rulers were never consulted. ${ }^{4}$ One member of royalty strongly opposed the accession by stating that:

\begin{abstract}
"[It] is a move that is against the Federal Constitution because it touches on the powers of the monarch, Malay special privileges, and the sanctity of Islam in this country," and reminded the government to "not follow any international conventions to get recognition from outsiders, but will, in the end, destroy national sovereignty." 5
\end{abstract}

\footnotetext{
${ }^{1}$ The Rome Statute of the International Criminal Court, adopted at Rome on 17 July 1998, entered into force on 1 July 2002, 2187 U.N.T.S 3 [hereinafter "Rome Statute"].

2 "Malaysia Accedes to the Rome Statute of the International Criminal Court," Press Release, Ministry of Foreign Affairs: Wisma Putra, Putra Jaya, 4 March 2019.

3 United Nations Secretariat, Depository Notification, C.N. 69. 2019.TREATIES -XVIII.10.

${ }^{4}$ Tashny Sukumaran, "Malaysia Backtracks on Decision to Join International Criminal Court Amid Royal Opposition," South China Morning Post, 5 April, 2019, $\quad$ https://www.scmp.com/news/asia/southeastasia/article/3004890/malaysia-backtracks-decision-join-international-criminal, accessed 21 October 2019.

5 "Putra Jaya Violated Federal Constitution with Rome Statute - Johor Sultan," Malaysia Kini, 23 March 2019, https://www.malaysiakini.com/news/469261.
} 
Similar voices were echoed by opposition law-makers. ${ }^{6}$

The Government backed off and Prime Minister Tun Dr. Mahathir Mohamad declared the Cabinet's decision to withdraw from the Rome Statute on 5 April 2019 in these terms: "There seems to be a lot of confusion about the Rome Statute, so we will not accede. This is not because we are against it, but because of the political confusion about what it entails, caused by people with vested interests."'7

Meanwhile, some conscientious and responsible academics and legal experts have pointed out that those who took a position against the Rome Statute have an erroneous understanding of the (factual as well as legal) issues. ${ }^{8}$ Shad Saleem Faruqi, for example, hit the nail on the head when he commented that:

"The opposition to the Rome Statute is on the frivolous ground that it would destroy the immunity of the Rulers, the special position of the Malays and the position of Islam. These fears are absolutely unfounded and bereft of logic, and appear to be based on advice that is motivated by politics, not law, emotion, not reason. The advice misleads Their Majesties...."9

6 "Malaysia's Move to Accede to Rome Statute Unconstitutional, Opposition MPs Claim," New Straits Times, March 26, 2019, https://www.nst.com.my/news/nation/2019/03/473161/malaysias-move-accederome-statute-unconstitutional-opposition-mps-claim, accessed 9 October 2019.

7 "Malaysia Withdraws from the Rome Statute," The Star Online, 5 April 2019, https://www.thestar.com.my/news/nation/2019/04/05/malaysia-withdraws-fromthe-rome-statute, accessed 10 October 2019; See also "KL's Rome Statute UTurn A Move to Prevent Coup - Minister," The Straits Times, 8 April 2019, https://www.straitstimes.com/asia/se-asia/kls-rome-statute-u-turn-a-move-toprevent-coup-minister, accessed 19 October, 2019.

${ }^{8}$ Syed Farid Alatas, "Against the Grain: The Rome Statute and Academic Responsibility," The Edge Malaysia Weekly, 24 April 2019, https://www.theedgemarkets.com/article/against-grain-rome-statute-andacademic-responsibility, accessed 12 October 2019; Lim Wei Jiet, "A Rebuttal of the Alleged Academic Presentation to Rulers," Malaysia Kini, 8 April 2019, https://www.malaysiakini.com/news/471305, accessed 10 October 2019.

${ }^{9}$ Shad Saleem Faruqi, "Treaty on ICC No Threat to Royals," The Star Online, Reflecting on the Law, 28 March 2019, 
The PH government was perhaps quite overzealous to make a decision to accede to the Rome Statute without extensively engaging with various stake holders and the people in general. ${ }^{10}$ The opposition very cleverly took the opportunity and effectively persuaded the royalty as well as the people with pure political rhetoric that lacks correct and logical interpretation of the law. The people should know the truth and it is of utmost importance to make the record straight. Although there are quite a number of issues revolving around the debate on accession to the Rome Statute, misconceptions surrounding the issue of sovereignty played a major role. The present paper, therefore, will focus on the 'issue of sovereignty, as its primary objective, and the other issues will be dealt with in a series of papers later on.

The following are the specific objectives of the present paper on the issue of sovereignty:

(1) To reappraise the concept of sovereignty in the light of contemporary international law;

(2) To evaluate the opposition of the Rome Statute by some powerful States on the ground of eroding national sovereignty;

(3) To assess the argument in the Malaysian context on erosion of national sovereignty to accede to the Rome Statute.

\section{REAPPRAISAL OF THE CONCEPT OF SOVEREIGNTY IN THE LIGHT OF CONTEMPORARY INTERNATIONAL LAW}

The term 'sovereignty' has been used since early time in history ${ }^{11}$ and its meaning could be rather elusive at times. ${ }^{12}$ According to Sahovic and

https://www.thestar.com.my/opinion/columnists/reflecting-on-thelaw/2019/03/28/treaty-on-icc-no-threat-to-royals, accessed 12 October 2019. ${ }^{10}$ Prashant Waikar, "Malaysia and the Rome Statute: Domestic Debate Over?" RSIS Commentary, S. Rajaratnam School of International Studies, Nanyang Technology University, Singapore, 21 May, 2019, https://www.rsis.edu.sg/rsispublication/rsis/malaysia-and-the-rome-statute-domestic-debateover/\#.XbEFhkYzZPY, accessed 10 October, 2019.

11 See Sir Robert Jennings, \& Sir Arthur Watts (eds.), Oppenheim's International Law, Vol 1, Peace, Introduction and Part I, $9^{\text {th }}$. ed. (London: Longman, 1996) 124, foot note 1. 
Bishop, "Sovereignty as a concept of international law has three major aspects: external, internal and territorial." 13 The two commentators set out the three aspects as follows:

"The external aspect of sovereignty is the right of the state freely to determine its relations with other states or other entities without the restraint or control of another state. This aspect of sovereignty is also known as independence. It is this aspect of sovereignty to which the rules of international law address themselves primarily. External sovereignty of course presupposes internal sovereignty."

"The internal aspect of sovereignty is the state's exclusive right or competence to determine the character of its own institutions, to ensure and provide for their operation, to enact laws of its own choice and ensure their respect."

"The territorial aspect of sovereignty is the complete and exclusive authority which a state exercises over all persons and things found on, under or above its territory. As between any group of independent states the respect for each other's territorial sovereignty is one of the most important rules of international law." 14

As Richard Falk rightly put it, "the history of the concept of sovereignty is one of conceptual migration." 15 The following is an analysis of the evolution of the concept of sovereignty as to how it gradually transformed from its inception as an absolute authority above which there is no other authority to its modern conception of internal and external aspects of sovereignty. This dramatic evolution will be proven by reference to State practice, doctrine and judicial pronouncements.

12 James Crawford, The Creation of States in International Law, $2^{\text {nd }}$. ed., (Oxford: Clarendon Press, 2011), 32;

Dan Sarooshi, "The Essentially Contested Nature of the Concept of Sovereignty: Implications for the Exercise by International Organizations of Delegated Powers of Government," Michigan Journal of International Law, 25:4 (2004): 1107.

${ }^{13}$ Milan Sahović \& William W. Bishop, "The authority of the State," in Max Sorenson (ed), Manual of Public International Law (Toronto: Macmillan, 1968) at 523 .

${ }^{14}$ Ibid.

${ }^{15}$ Richard Falk, "Sovereignty" in J. Krieger (ed.) The Oxford Companion to Politics in the World, $2^{\text {nd }}$ ed. (Oxford: Oxford University Press, 2001) 789. 


\section{The origin: Sovereignty as absolute and unlimited power}

The original theoretical model of State sovereignty is often attributed to the French jurist Jean Bodin (1530-1596) and can be found in his book: Les Six livres de la Republique (Six Books of the Republic), published in 1576. According to Bodin, sovereignty is "absolute, perpetual and indivisible power and it cannot by definition be subject to any rule or restriction." 16 He was apparently influenced by the Roman law ideas of summum imperium (the highest authority) and merum imperium (unqualified authority). ${ }^{17}$ After Bodin, however, a number of political scientists, such as John Locke ${ }^{18}$ and Jean-Jacques Rousseau, ${ }^{19}$ talked about 'internal sovereignty' that challenged the concept of absolute sovereignty.

Peace treaties, commonly known as the 'Peace of Westphalia,' were adopted in $1648 .{ }^{20}$ The Peace of Westphalia set up "a new system of political order in Europe based upon the concept of co-existing sovereign States". This is known as 'Westphalian sovereignty,' according to which "each State has sovereignty over its territory and domestic affairs to the exclusion of all external powers and all States are equal in terms of sovereignty." 21

16 Jean Bodin, On Sovereignty, Julian H. Franklin (trans \& ed) (Cambridge: Cambridge University Press, 1992).

17 "Theory of Sovereignty," Encyclopedia.com, https://www.encyclopedia.com/history/encyclopedias-almanacs-transcripts-andmaps/sovereignty-theory, accessed 12 October 2019.

18 John Locke, Two Treatises of Government, ed. Peter Laslett (New York: Mentor, 1965), 310, 318, 351.

19 Jean-Jacques Rousseau, The Social Contract and Discourse on the Origin of Inequality, ed. Lester G. Crocker (New York: Pocket Books, 1967), 93.

${ }^{20}$ Leo Gross, "The Peace of Westphalia," American Journal of International Law, 42 (1948): 21

${ }^{21}$ Stephane Beaulac, "The Westphalian Model in Defining International Law: Challenging the Myth," Australian Journal of legal History, 8 (2004): 181-213, at 181. 


\section{The evolution of the concept of sovereignty: the rise of external aspect of sovereignty}

It is only in the $19^{\text {th }}$ century that the idea of 'external sovereignty' of the State in its international relations was properly conceptualized. This coincides with the development of international law alongside the domestic laws of each sovereign State. In relation to the idea that sovereignty (the external aspect of sovereignty) is inherently limited and it is limited by international law, Besson rightly put it this way:

"It rapidly became clear that international law and sovereignty implied each other. To be fully in charge of its relations with other States in a society of equally sovereign States and to be externally sovereign, and hence in turn to be able to protect its internal sovereignty, a State needed to be submitted to international law. However, for international law to arise, it needed independent sovereign States to freely consent to mutual rights and obligations and to their regulation. As a result, since sovereignty implies the existence of international law, it became selfevident that sovereignty is inherently limited. Even if, by definition, $a$ sovereign State cannot be limited by the laws of another State, it may be limited by international law, that is, the law that results from the collective will of all States."22

\section{The modern concept of sovereignty: correlation between sovereignty and international law}

The first half of the $20^{\text {th }}$ century was the period when the modern international law emerged. Together with this development of modern international law, the modern concept of sovereignty was also being finally crystalized.

Oppenheim has reminded us about the danger of transposing the traditional concept of 'absolute sovereignty,' which was in the past conceptualized as the highest and unlimited power of a sovereign over everything within the State - essentially internal concept of sovereignty, on to the international plane through the emergence in some instances of

${ }^{22}$ Samantha Besson, 372 [emphasis added]. 
extreme nationalism. ${ }^{23}$ The learned scholar succinctly rationalizes his idea in these words:

"Sovereignty as supreme legal power and authority is inapplicable to the position of States within the international community: no State has supreme legal power and authority over other States in general, nor are States generally subservient to the legal power and authority of other States. Thus the relationship of States on the international plane is characterized by their equality and independence and, in fact, by their interdependence. Although States are often referred to as 'sovereign' States, that is descriptive of their internal constitutional position rather than of their legal status on the international plane."24

Superiority of international law over national law in the international sphere

International law can simply be defined as a body of rules of conduct binding upon States in their mutual relations. This very notion of international law implies the idea of States' subjection to international law. ${ }^{25}$ This is reinforced by the rule pacta sunt servanda ${ }^{26}$ which has been codified in Article 26 of the Vienna Convention on the Law of Treaties 1969 (VCLT) in the following manner:

Every treaty in force is binding upon the parties to it and must be performed by them in good faith. ${ }^{27}$

The corollary to the above idea of superiority of international law over national law in the international sphere can be found in Article 27 of the VCLT:

${ }^{23}$ Sir Robert Jennings, \& Sir Arthur Watts (eds.), Oppenheim's International Law, Vol 1, Peace, Introduction and Part I, $\left(9^{\text {th }}\right.$. ed., London: Longman, 1996) 125.

${ }^{24}$ Ibid.

${ }^{25}$ Article 14 of the Draft Declaration on Rights and Duties of States, adopted by the International Law Commission in 1949 provides that "Every State has the duty to conduct its relations with other States in accordance with international law and with the principle that the sovereignty of each State is subject to the supremacy of international law." Yearbook of the International law Commission, (1949) 286-90.

${ }^{26}$ Pacta sunt servand is a Latin term, meaning: "agreements must be kept."

${ }^{27}$ The Vienna Convention on the Law of Treaties, 1969, Article 26. 
A party may not invoke the provisions of its internal law as justification for its failure to perform a treaty. ${ }^{28}$

Again, this principle is reflected in Article 3 of the International Law Commission's Articles on Responsibility of States for Internationally Wrongful Acts 2001, which provides that:

The characterization of an act of a State as internationally wrongful is governed by international law. Such characterization is not affected by the characterization of the same act as lawful by internal law. ${ }^{29}$

Judicial pronouncements on superiority of international law in the international sphere

International courts and tribunals have consistently held that in the event of conflict between international obligations and national law, the international rule prevails. For instance, in the Alabama Claims Arbitration, the Tribunal held that "Great Britain could not rely on the absence of domestic legislation as a reason for non- fulfilment of its international law obligations of neutrality in the American Civil War." 30 In the same vein, in Exchange of Greek and Turkish Populations case, the World Court decided that:

A State which has contracted valid international obligations is bound to make in its legislation such modifications as may be necessary to ensure the fulfilment of the obligations undertaken. ${ }^{31}$

Again in Free Zones of Upper Savoy and the District of Gex case, the court held that "France could not rely on her own legislation to limit the scope of her international obligations." 32 In LaGrand case, ${ }^{33}$ the

\footnotetext{
${ }^{28}$ Ibid., Article 27.

29 The International Law Commissions Articles on Responsibility of States for Internationally Wrongful Acts, 2001, adopted by the GA Res 56/ 83, December 12, 2001, Art 3.

${ }^{30}$ The Alabama Claims Arbitration (USv GB) Moore 1 Int Arb 495.

${ }^{31}$ Exchange of Greek and Turkish Populations, Advisory Opinion (1925) PCIJ Reports Series B, No 10, 20.

${ }^{32}$ Free zones of Upper Savoy and the District of Gex case (1932) PCIJ Series A/ B, No 46.
} 
International Court of Justice ruled that "although the national authorities were complying with their national law it was a violation of international law and thus an apology for any future violations of Article 36 of the Convention would be inadequate reparation," and that "the US must allow review and reconsideration of the conviction and sentence in the light of the violation of the rights in the Convention." ${ }^{34}$

The emergence of the United Nations and the proliferation of international organizations is an irrefutable evidence for subjection of sovereign States to international law

The second part of the $20^{\text {th }}$ century (in particular after the establishment of the United Nations in 1945) is the period when the new conception of international law as the law of cooperation between sovereign States has been firmly established. Since 1945, international organizations have proliferated globally as well as regionally. The creation of the United Nations in 1945 is a striking example.

The United Nations is the most important inter-governmental organization of the time. The Charter is the paramount multilateral lawmaking treaty of the present-day. By virtue of the influence of the Charter and numerous resolutions and decisions made by the principal organs of the United Nations, international law has changed and developed enormously. It has developed so much so that international law in the past (that is pre-UN Charter international law) and international law after 1945 (post-UN Charter International law) are essentially different in many respects. The use of military force in inter-State relations is no longer lawful. Article 2(4) of the UN Charter categorically prohibits the use of force ${ }^{35}$ and this prohibition of the use of force is a rule having the character of jus cogens - a peremptory norm from which no derogation is permitted. ${ }^{36}$ Since this is a prohibition imposed on all States, it

${ }^{33}$ LaGrand case (Germany v United States of America), Merits (2001) ICJ Rep 466.

${ }^{34}$ LaGrand case, Merits, para 125.

35 The Charter of the United Nations, Article 2(4).

${ }^{36}$ Military and Paramilitary Activities in and Against Nicaragua (Nicaragua $v$ United States) (Merits) (1986) ICJ Rep 14 (hereinafter the Nicaragua case (Merits)) at 103, para 195. 
encroaches upon the Westphalian style of absolute sovereignty. The prohibition shows very clearly that States no longer have any absolute sovereignty and their sovereignty is limited by this and many other rules of international law. Since the prohibition is a rule of jus cogens, the violation of this would be tantamount to committing an international crime: the crime of aggression.

Article 2(1) of the UN Charter reaffirms the doctrine of sovereign equality of States. ${ }^{37}$ However, a remarkable exception to this doctrine is the crucial role of the Big Five - the five permanent members of the UN Security Council. ${ }^{38}$ They have two special privileges: (i) they are forever permanent members and nobody can dethrone them from this position; ${ }^{39}$ and (ii) they have the veto power (each permanent member has the power to forbid any resolution they do not like to adopt). ${ }^{40}$ Again, according to Article 25 of the Charter, "All UN member States agree to accept and carry out the decisions of the Security Council," in which the Big Five play the decisive role. By virtue of this crucial provision, the decisions (resolutions) of the SC are legally binding on all member States and they are obliged to comply. It implies that the SC has quasi-legislative power and decisions of the SC are law for the States to follow. Furthermore, under Chapter VII of the UN Charter, the Security Council, as the enforcement arm of the UN, has the power to determine what enforcement measures should be taken (economic and other sanctions or even military measures) against a State. ${ }^{41}$

Although the general rule is that the United Nations cannot intervene in matters which are essentially within the domestic jurisdiction of any State (principle of non-intervention), the proviso to that general rule is that "this principle shall not prejudice the application of enforcement

\footnotetext{
37 The Charter of the United Nations, Article 2(1). On the relationship between State sovereignty and the Charter, see also Bruno Simma et al, The Charter of the United Nations: A Commentary ( $3^{\text {rd }}$. ed., Oxford: Oxford University Press, 2013) 68-91.

38 The Charter of the United Nations, Article 23.

${ }^{39}$ See Ibid., Article 108; The UN Charter can be amended only when all the Big Five unanimously agree. It means that each of the Big Five has the veto power and without their agreement no amendment to the Charter can be made.

${ }^{40}$ Ibid., Article 27(3).

${ }^{41}$ Ibid., Articles 39, 41 and 42.
} 
measures under Chapter VII." ${ }^{42}$ In Nationality Decrees in Tunisia and Morocco case, the PCIJ defines 'domestic matter' as a "matter in which the State is free from international obligations of any kind." ${ }^{43}$ According to the general rule, if it is essentially within its domestic jurisdiction, a State can maintain its (internal) sovereignty and the UN cannot intervene. However, a matter ceases to be a domestic matter "if it amounts to a breach of international law, an infringement of the interests of other States, or a threat to international peace and security." In this scenario, no State can argue, on the ground that it is a sovereign State, against a resolution of the Security Council to take enforcement measures.

To sum up, all the above State practice and judicial pronouncements can well be interpreted as restrictions on sovereignty of States. The modern concept of sovereignty, as is exemplified in the current practice of States within the international sphere (that is external sovereignty) is not absolute. It is limited and subjection to international law is the limiting factor. According to the positivist doctrine, the limitations on sovereignty are imposed by States themselves on the basis of their own free will (by means of express consent: treaties; or implied consent: customary international law).

In an increasing number of cases, however, international law seems to be limiting States' sovereignty even without their consents. This is primarily based on the idea of naturalist doctrine. A landmark milestone of the naturalist doctrine is the emergence of the concept of jus cogens ${ }^{44}$ or peremptory norms of general international law from which no derogation is permitted. ${ }^{45}$

\footnotetext{
42 Ibid., Article 2(7).

${ }^{43}$ Nationality Decrees in Tunisia and Morocco case (1923) PCIJ Series B No 4 at 24.

44 Jus cogens is a Latin term meaning "compelling law."

45 Vienna Convention on the Law of Treaties, 1969, Article 53. See Antonio Cassese, International Law, (2001), 138-139. See also Li Haopei, “Jus Cogens and International Law" in Sienho Yee and Wang Tieya (eds), International Law in the Post-Cold War World: Essays in Memory of Li Haopei (London: Routledge, 2001), 499-501.
} 


\section{OBJECTIVE ANALYSIS OF ARGUMENTS MADE BY SOME POWERFUL STATES AGAINST THE ROME STATUTE}

To establish a permanent international criminal court had been the dream of the international community for so many years. In order to materialize the dream, a diplomatic conference was met in Rome, Italy, in 1998 for the adoption of a convention, in the form of a Statute, to establish the international criminal court. The number of participants at the Rome Conference was overwhelming: 160 States, 33 international organisations and a group of 236 non-governmental organisations (NGOs). "The Statute of the International Criminal Court was finally adopted by the Rome Conference on 17 July, 1998, by a vote of 120 States in favour, 7 against and 21 abstentions." Among the Big Five, France, the United Kingdom and Russia supported the Statute but the United States opposed it bitterly. China and Israel joined the United States in voting against the Statute. The Rome Statute entered into force on 1 July 2002. Currently, it has 136 signatories and 122 States parties. It means that although there are opposing States, the overwhelming majority of States embrace the Rome Statute.

It has been argued that the United States is concerned about its numerous overseas military personnel around the world in view of the fact that as the world's sole superpower, it has greater military commitments than any other country. ${ }^{46}$ However, as a matter of fact, the United States has been all this while following its avowed policy of 'unilateralism' as opposed to 'multilateralism. ${ }^{47}$ Unilateralism appears to denote the situation of a State that acts alone in disregard of the wish of the international community. ${ }^{48}$ It clearly reflects the position of the

${ }^{46}$ Matthew A. Barrett, "Ratify or Reject: Examining the United States' Opposition to the International Criminal Court," Georgia Journal of International and Comparative Law, 28 (1999): 83, at 84.

${ }^{47}$ Johannes Thimm, The United States and Multilateral Treaties: A Policy Puzzle, (Boulder: First Forum Press, A Division of Lynne Rienner Publishers Inc, 2016), 2.

48 For a comprehensive study of 'unilateralism', see Jeffrey S. Lehman, "Unilateralism in International Law: A United States - European Symposium", EJIL 11 (2000), No.1, 1-2; Pierre-Marie Dupuy, "The Place and Role of Unilateralism in Contemporary International Law", ibid., 19-30; Christine Chinkin, "The State That Acts Alone: Bully, Good Samaritan or Iconoclast?", Ibid., 31-42. 
United States in respect of the contemporary international law issues. The United States, for example, did not comply with the judgment of the World Court in the Nicaragua Case. ${ }^{49}$

The United States also has rejected to adopt a number of prominent multilateral law-making treaties. To name a few, it has not ratified or has rejected the following: "International Covenant on Economic, Social and Cultural Rights (ICESCR), 1966 (170 States parties); Convention on the Elimination of All Forms of Discrimination Against Women (CEDAW), 1979 (189 States parties); Convention on the Law of the Sea (UNCLOS), 1982 (168 States parties); Convention on the Rights of the Child (CRC), 1989 (196 States parties); Convention on Biodiversity, 1992 (196 States parties); Convention on Anti-Personnel Mines (Ottawa Convention), 1997 (164 parties); Kyoto Protocol to the UN Framework Convention on Climate Change, 1997; Rome Statute of the International Criminal Court (ICC), 1998 (122 States parties)." ${ }^{50}$ Some of these conventions achieved universal adherence (the US is the only State that rejects) and others are adhered to by the overwhelming majority of the international community. It means that the Rome Statute is not the only treaty rejected by the US; it is in fact just a reflection of the United States' unilateralism.

Although there are a variety of reasons given by the US on why it could not accept the Rome Statute, the primary consideration in the words of the head of the United States delegation to the Rome Conference were the following: "the assumed role of the United States within a global system, that also requires our constant vigilance to protect international peace and security...far more than any other nation." ${ }^{51}$ The meaning of the statement is quite clear: "a US soldier should not, and cannot, be submitted to the jurisdiction of the Court on account of the enormous responsibility taken by the US for the maintenance of international peace and security."

The primary attitude of the United States is simple enough: it is reluctant to submit to any higher authority and claims to exceptionalism

${ }^{49}$ Military and Paramilitary Activities in and against Nicaragua, \{Nicaragua v United States], (Merits), 1984 ICJ Rep. 14.

${ }^{50}$ Johannes Thimm, The United States and Multilateral Treaties: A Policy Puzzle, 6 .

${ }^{51}$ D. Scheffer, "The United States and the Criminal Court", American Journal of International Law, 93 (1999): 12-22, at 12. 
due to its great power status. Many countries probably see it this way. ${ }^{52}$ So far as scholars are concerned, Professor David of the Michigan Law School arrives at the following conclusion:

"Indeed the US repudiates the principle of Nuremberg by insisting that America (the State with the most political and military power) should be exempt from the law: it really was victor's justice after all." ${ }^{53}$

Other powerful countries like China and Israel also appears to have ulterior motive to oppose the Rome Statute. Like the US, China, as an emerging super power, would not also like to submit to any higher authority. The repression of Tibetans in Tibet Autonomous Region and Uighurs Muslims from the Xinjiang Uighur Autonomous Region ${ }^{54}$ are thorny issues for China to be worried about submitting to higher authorities. The main problem with Israel is the claims of war crimes and crimes against humanity allegedly committed by Israeli armed forces against Palestinians. It is common knowledge that "Israel is finding itself vulnerable to International Criminal Court (ICC) prosecution in the face of brazen, recurring and well-documented crimes against Palestinians. Now that Palestine has joined the ICC, Israel is finding itself in a legal bind." 55

Whatever the ulterior motive is, the main arguments put forward by the United States and other powerful States will be objectively analysed in the following sections on the basis of good faith interpretation of the relevant provisions of the Rome Statute.

52 Abdul Ghafur Hamid, "Towards the Establishment of an International Criminal Court,” IIUM Law Journal, 8:2 (2000): 171-182.

${ }^{53}$ M. David. "Grotius Repudiated: The American Objections to the International Criminal Court and the Commitment to International Law", Michigan Journal of International Law 20 (1999), 337-412, at 409.

${ }^{54}$ Lindsay Maizland, "China's Repression of Uighurs in Xinjiang," Council on Foreign Relations, 9 October 2019, https://www.cfr.org/backgrounder/chinas-repression-uighurs-xinjiang, accessed 21 October, 2019.

${ }^{55}$ Ramzy Baroud, "Israeli War Crimes Must not Go Unpunished," Gulf News, 11 June 2019, https://gulfnews.com/opinion/op-eds/israeli-war-crimes-must-not-gounpunished-1.64507744, accessed 10 October 2019. 


\section{Argument that the Rome Statute Imposes Obligations on Non-States Parties}

One of the major objections to the ICC by China, ${ }^{56}$ India, ${ }^{57}$ and the United States ${ }^{58}$ is that "the Rome Statute of the International Criminal Court imposes obligations on non-States Parties and therefore violates Article 34 of the Vienna Convention on the Law of Treaties (VCLT)," which provides that "a treaty does not create either obligations or rights for a third State without its consent." 59

The above argument, however, is without merit. In fact, the International Criminal Court exercises criminal jurisdiction only over individuals, not over States. ${ }^{60}$ Article 1 of the Statute clearly sets forth that the Court "shall have the power to exercise jurisdiction over persons for the most serious crimes of international concern..." ${ }^{\prime 61}$ Again, Article 25 reaffirms the individual criminal responsibility as the foundation stone of the Rome Statute and rejects imposing responsibility on States in these terms: "No provision in this Statute relating to individual criminal responsibility shall affect the responsibility of States under international law." According to Article 12 "States are allowed to voluntarily accept or reject the jurisdiction of the ICC." ${ }^{\prime 2}$ Furthermore, Part 9 of the Statute,

${ }^{56}$ Lu Jianping \& Wang Zhixiang, "China's Attitude Towards the ICC," Journal Of International Criminal Justice, 3 (2005): 608, 611.

${ }^{57}$ Dilip Lahiri, "Explanation of India's Vote on the Adoption of the Statute of the International Criminal Court," in William Driscoll et al. eds, The International Criminal Court: Global Politics and the Quest for Justice, (New York: International Debate Association, 2004): 42, 43-44.

58 Jason Ralph, Defending the Society of States: Why America Opposes the International Criminal Court and Its Vision of World Society, (Oxford Scholarship Online, 2007): 130.

${ }^{59}$ Article 34, the Vienna Convention on the Law of Treaties, adopted at Vienna on 23 May 1969, U.N. Doc. A/CONF. 39/27.

${ }^{60}$ Diane F. Orentlicher, "Politics by Other Means: The Law of the International Criminal Court," 32 Cornell International Law Journal, 32 (1999): 489, 491 (noting that "the ICC was established to enforce a body of law whose very essence is its direct application to individuals - not States").

${ }^{61}$ Rome Statute, Article 1 (emphasis added). See Orentlicher, at 490.

62 The Rome Statute, Article 12(3); see Lu Jianping, at 612. 
which deals with cooperation and assistance, "imposes obligations only on States Parties." 63

Those who make the argument that the Court cannot exercise jurisdiction over nationals of non-party States appear to have confusion in their minds between the position of a non-party State and that of its nationals. That is why "this argument has been rejected by international law commentators on the simple basis that while a non-party State is not itself obligated under a treaty to which it has not consented, the same cannot be said of its nationals if they commit an offense in the territory of a State that is a party." 64

No provision of the Rome Statute expressly created obligations to non-party States. Michael Scharf posits that "It cannot therefore be argued that the Court's exercise of treaty-based jurisdiction over the nationals of non-party State for international crimes contravenes the VCLT." 65 Therefore, it is quite logical to conclude that "the argument that the Rome Statute is 'overreaching' because it purportedly obligates non-party States through the exercise of jurisdiction over their nationals is a gross distortion of customary international law."

Furthermore, the U.S. is a party to many multilateral law-making treaties (in particular, relating to hijacking of aircraft, terrorism, prohibition against torture, etc.) that are globally binding on nationals of party and non-party States alike because they reflect the "common interests of humanity." ${ }^{67}$ Again, according to the Restatement of Foreign

${ }^{63}$ Part 9 of the Rome Statute deals with "International Cooperation and Judicial Assistance."

${ }^{64}$ Ruth Wedgwood, Harold K. Jacobson \& Monroe Leigh, "The United States and the Statute of Rome," American Journal of International Law, 95 (2001): 124 , at 127.

${ }^{65}$ Michael P. Scharf, "Application of Treaty-Based Universal Jurisdiction to Nationals of Non-Party States," New England Law Review 35 (2001): 363, at 376.

${ }^{66}$ See Human rights Watch, "The ICC Jurisdictional Regime; Addressing U.S. Arguments," available at http://www.hrw.orglhrw/campaigns/icc/docs/iccregime.htm.

${ }^{67}$ See Convention on Offenses and Certain Other Acts Committed on Board Aircraft, 1963 (Tokyo Convention); Convention for the Suppression of Unlawful Seizure of Aircraft 1970, (Hague Convention); Convention for the 
Relations Law of the United States, "the first and best established jurisdictional principle is "territoriality'." ${ }^{68}$ The U.S. legislative practice also recognizes the principle of universal jurisdiction over crimes under international law such as piracy, the slave trade, genocide, and war crimes. ${ }^{69}$ Therefore, it is contrary to reason for the U.S. to argue that "the Court's exercise of jurisdiction against nationals of non-party States is a violation of fundamental principles of international law." 70

\section{Argument that Power Given to ICC to Decide on Unwillingness or Inability of a State to Investigate or Prosecute Violates State Sovereignty}

China $^{71}$ and India ${ }^{72}$ argue that "the ICC's complementarity regime violates State sovereignty because it permits the ICC to judge whether a State is able or willing to try its own nationals, thereby becoming a supranational organ."73 Cherif Bassiouni interprets the essence of the complementarity regime in these terms: "the complementarity principle contained in the Rome Statute is designed to encourage national legal systems to exercise jurisdiction, as opposed to promoting the ICC to

Suppression of Unlawful Acts Against the Safety of Civil Aviation, 1971 (Montreal Convention); The International Convention Against the Taking of Hostages, 1979; The Convention Against Torture and Other Cruel, Inhuman and Degrading Treatment or Punishment, 1984, ('Torture Convention). These treaties impose the obligation on both States of nationality and territorial States either to exercise jurisdiction or extradite. The U.S. is a party to all of these treaties.

${ }^{68}$ Restatement (Third) of Foreign Relations of the United States, Section 402 cmt. (American Law Institute, 1987).

${ }^{69}$ Ibid., Section 404.

${ }^{70}$ Remigius Chibueze, "United States Objection to the International Criminal Court: A Paradox Of 'Operation Enduring Freedom," Annual Survey of International \& Comparative Law, Vol. 9:1 [2003], Art. 3, at 36.

${ }^{71}$ Lu Jianping \& Wang Zhixiang, China's Attitude Towards the ICC, 3 Journal of International Criminal Justice 3 (2005): 608, at 613.

${ }^{72}$ Usha Ramanathan, "India and the ICC," Journal of International Criminal Justice, 3 (2005): 627, at 633.

${ }^{73} \mathrm{Lu}$ Jianping, at 613. 
assert jurisdiction." 74 To counter the claim that the scrutiny of domestic legal systems envisioned by Article 17 transgresses State sovereignty, "during the drafting process, the terminology in subsections (2) and (3), respectively, was strengthened, for example, the phrase 'undue delay' was changed to 'unjustified delay' and the phrase 'partial collapse' was heightened to 'substantial collapse.' 75

India further argued that under the complementarity principle in Article 17 "all nations must constantly prove the viability of their judicial structures or find these overridden by the ICC." 76 According to them, when making an assessment under Article 17: "[I]f the ICC gets to invalidate national trials by deciding what constitutes an 'effective' or 'ineffective' trial, the international court will exercise a kind of judicial review power over national criminal justice systems. In other words, the ICC will have de facto supreme judicial oversight." 77

However, even though it is assumed that the ICC has the power of alleged judicial review, there are more than enough safeguards in the Rome Statute. First, the decisions of the ICC on admissibility (unwillingness or inability) must be based on principles of due process of law. ${ }^{78}$ Secondly, the actual power to decide the issue of admissibility is vested only with the Court (the Chambers of ICC) and not with the Prosecutor. ${ }^{79}$ Thirdly, it is therefore not true, as argued by some quarters, that the Prosecutor has the power to arbitrarily decide the issue of

74 M. Cherif Bassiouni, "Explanatory Note on the ICC Statute," Revue Internationale De Droit Penal, 71 (2000): 1, 5 ("National criminal jurisdiction always has priority over the ICC, and in only two situations can the ICC exercise its jurisdiction [Article 17]...").

75 Steven W. Becker, "The Objections of Larger Nations to the International Criminal Court," International Review of Penal Law, 81:1 (2010): 47-64, at 50. ${ }^{76}$ Usha Ramanathan, at 633.

77 Gary T. Dempsey, "Reasonable Doubt: The Case against the Proposed International Criminal Court," in William Driscoll et al. eds, The International Criminal Court,: Global Politics and the Quest for Justice, (New York: International Debate Association, 2004): 48, 52.

78 The Rome Statute, Article 17(2): "In order to determine unwillingness in a particular case, the Court shall consider, having regard to the principles of due process recognized by international law...."

${ }^{79}$ Ibid. Article 17 (1): "the Court shall determine that a case is inadmissible." 
admissibility. He/she can just initiate preliminary investigations if there is a reasonable basis to commence them. However, the affected State can inform the ICC that it is actually investigating the situation and in that case the Prosecutor has to defer. ${ }^{80}$ Fourthly, the burden of proof lies on Prosecutor to prove that a State is unable or unwilling to prosecute, or that investigations and trials carried out by a State are a sham. ${ }^{81}$ It is not, therefore, true that the State concerned has to always prove the viability of their judicial structures. Finally, the decision of the Pre-Trial Chamber on admissibility again can be challenged by the State before the Appeals Chamber. ${ }^{82}$ This is aptly illustrated in the case of Prosecutor $v$ Katanga $^{83}$ decided by the Appeals Chambers of the ICC in 2009.

To sum up, although it can be said that the final arbiter for the determination of the admissibility (to decide whether domestic authorities have willingness or ability to investigate or prosecute) is the Court itself, it is indeed an inherent right of any court of justice and there are ample procedural safeguards to maintain fairness and due process of law. In this regard, Sandra Jamison argues that "States must prepare to cede some of their traditional sovereignty in pursuit of a potent international criminal court. The absolute doctrine that a State is supreme in its own authority, and need not take into account the affairs of other nations, is no longer tenable." ${ }^{84}$ And, as one commentator candidly admitted that the noble objective of putting an end to impunity for perpetrators of heinous international crimes "cannot be achieved without impinging upon the

${ }^{80}$ Ibid. Article 18 (1), (2) \& (3). According to Article 18(4), "The State concerned or the Prosecutor may appeal to the Appeals Chamber against a ruling of the Pre-Trial Chamber, in accordance to Article 82."

${ }^{81}$ Ibid., Article 17(2)(3).

${ }^{82}$ Ibid., Article 18(4); Article 19 (challenges to jurisdiction or admissibility).

${ }^{83}$ The Prosecutor v Germain Katanga and Mathieu Ngudjolo Chui, (Appeals Chamber) Judgment of 25 September 2009, ICC-01/04-01/07 OA 8.

${ }^{84}$ See Sandra L. Jamison, "A Permanent International Criminal Court: A Proposal That Overcomes Past Objections," Denver Journal of International Law and Policy, 23 (1995): 419, 432 (reasoning that an international criminal court would allow nations to prosecute crimes that were formerly out of their power). 
traditional criminal jurisdiction of States, but the values concerned are important enough to justify this intrusion." 85

\section{Argument that ICC May Exercise Jurisdiction without Consent of State of Nationality}

One of the major arguments of the United States relates to the consent regime established by Article 12 of the Rome Statute. According to the Article, the ICC may exercise its jurisdiction "if either the State in whose territory the crimes was committed or the State of which the person accused is a national, is a State party to the Rome Statute." $" 86$

The United States argues that "such a jurisdictional regime is inconsistent with the principle of sovereign consent because it would permit the prosecution of U.S. nationals before the ICC based solely on the consent of the nation on whose territory the conduct occurred, without U.S. approval." 87 Instead, the United States argues that "the consent of the State of nationality should be required, in addition to the territorial State." 88

The US position on this point, however, is very weak. First of all, according to Cherif Bassiouni, "it has long been established that, based upon the principle of territorial jurisdiction, the State on whose territory a crime took place had the right to try the accused, regardless of whether that individual was a citizen or not." 89 Secondly, any human being (whether a US citizen or a citizen of whichever State) who commits a crime in the territory of a foreign State will be arrested by the police and

85 Bartram S. Brown, "Primacy or Complementarity: Reconciling the Jurisdiction of the National Courts and International Criminal Tribunals," Yale Journal of International Law, 23 (1998): 383, 434-35.

${ }^{86}$ Rome Statute, Article 12(2).

${ }^{87}$ Steven W. Becker, at 54.

${ }^{88}$ Hans-Peter Kaul, "Preconditions to the Exercise of Jurisdiction," in Antonio Cassese et al. eds, The Rome Statute of the International Criminal Court: A Commentary, volume 1, (Oxford: Oxford University Press, 2002), 600.

89 M. Cherif Bassiouni, "Explanatory Note on the ICC Statute," Revue Internationale de Droit Penal, 71 (2000): 1, 8. ("It is clearly established in international law that whenever a crime is committed on the territory of a given State, it can prosecute the perpetrator even when that person is a non-national'). 
tried and convicted by the court of that country, without asking the consent of the US or the national State of the accused, and this is an established rule of customary international law. ${ }^{90}$ If even an ordinary domestic court can exercise jurisdiction over a foreigner for the crime he committed within its territory without the consent of his national State, there could not be any rational reason for objecting an international criminal court not to exercise such a jurisdiction.

Furthermore, it is admitted by Scheffer that "U.S. is not opposed to the Court's subject matter jurisdiction on genocide, war crimes and crimes against humanity." ${ }^{91}$ Amell is of the following view: "According to existing customary international law, any individual State may try perpetrators of these crimes under the universal or territorial principle of jurisdiction and that State would not need consent from another State (the State of nationality). Thus, if individual State can exercise on the basis of universal or territorial principle of jurisdiction over the same crimes contained in the ICC Statute, there has not been any convincing legal argument to deny a group of States joining together to set up a court that does the same thing." 92

The above mentioned analysis of the main objections to the ICC by some of the most powerful States of the world and responses to these objections clearly demonstrate the fact that the vast majority of fears and concerns are unfounded. Since the Rome Statute is a treaty, States are free to accept or reject it. Nobody can force them to ratify or accede to it unless the States themselves believe that it is in their best interests to do so. Yet, it is hoped that this analysis will help to dispel many of the misconceptions revolving around the Rome Statute.

\footnotetext{
${ }^{90}$ Hans-Peter Kaul, at 609.

${ }^{91}$ David J. Scheffer, "The United States and the International Criminal Court," American Journal of International Law, 93 (1999): 12, at 12-13.

92 Paul Amell, "International Criminal Law and Universal Jurisdiction," International Legal perspective 2(1999): 53, 60-63. Also see Attorney-General of Israel v. Adolf Eichmann, (Israel S.C 1962), 36 ILR 5, 26.
} 


\section{MALAYSIA'S SOVEREIGNTY AND THE ROME STATUTE: THE ARGUMENTS}

Sovereignty is dear to everyone and in particular to those who love their country above all else. Politicians therefore took this opportunity and poisoned the heart of those ordinary people by scaring them to believe that Malaysia will lose its sovereignty if it accedes to the Rome Statute. The main question to be addressed here therefore is: will accession to the Rome Statute erode the sovereignty of Malaysia?

The answer of the former Chief Justice of Malaysia Tun Abdul Hamid Mohamad to the above question is the following:

"It is true that by accepting it, we give to state parties the right to refer the commission of the said crimes in Malaysia or by Malaysian nationals to ICC (but we may also do the same with respect to other state parties) and we give jurisdiction to the ICC to try Malaysian nationals. The fact is that when a country becomes a state party to an international treaty, it will be bound by the terms and provisions of the treaty, which will somehow affect its sovereignty. That is inevitable. Moreover, it will involve all parties, not only Malaysia." 93

Tun does not argue that the accession erodes or destroys sovereignty of Malaysia but rather give a wise answer that it "will somehow affect its sovereignty." As a matter of fact, entering into a treaty by no means erodes or destroys sovereignty of a State; the sovereignty is intact. It may of course affect or restrict sovereignty to the extent of the obligation taken. Most importantly, entering into a treaty is indeed an exercise of State sovereignty and a State does it of its own free will and free consent (positivist doctrine; consensual theory).

\section{Entering into a Treaty: an Attribute of State Sovereignty}

Capacity to make treaties is, in fact, valuable evidence of statehood and a reflection of State sovereignty. ${ }^{94}$ That is why the PCIJ recognised in the

\footnotetext{
93 Tun Abdul Hamid Mohamad, "Rome Statute of the ICC: Should Malaysia Ratify it?" $22 \quad$ March 2019, 3-4, http://www.tunabdulhamid.my/index.php/speech-papers-lectures/item/931rome-statute-icc-should-malaysia-ratify-it?, accessed 11 October 2019. ${ }^{94}$ See Vienna Convention on the Law of Treaties, 1969, Article 6.
} 
Wimbledon case that "the right to enter into international engagements is an attribute of State sovereignty." ${ }^{\circ 5}$ This principle was reaffirmed in later decisions of the PCIJ ${ }^{96}$ as well as by its successor: the ICJ. In the Nicaragua case, the Court observed that a State can undertake by international agreement to adopt a particular domestic policy. ${ }^{97}$

The following ruling of Judge Anzilotti in Austro-German Customs Regime case has become the classic statement of international law:

\begin{abstract}
"Independence ... is really no more than the normal condition of States according to international law; it may also be described as sovereignty (suprema potesta)... by which is meant that the State has over it no other authority than that of international law ... It follows that ...the restrictions upon a State's liberty, whether arising out of ordinary international law or contractual engagements, do not as such in the least affect its independence. As long as these restrictions do not place the state under the legal authority of another State, the former remains an independent State however extensive and burdensome these obligations may be." ${ }^{98}$
\end{abstract}

\title{
The decisive factor: to consider whether restraining sovereignty of a State by means of a treaty is the right thing to do
}

A crucial question that can be raised, however, is: why do States commit to a treaty? A number of scholars have offered theories to explain why States might decide to ratify treaties. Under the "rationalist view," "States will consider their own material interests and only join treaties where the costs of commitment are small or outweighed by benefits that

${ }^{95}$ S.S. Wimbledon, Judgment of 17 August 1923, PCIJ Ser. A, No. 1, at 25. ${ }^{96}$ Exchange of Greek and Turkish Populations, PCIJ Ser. B, No. 10 (1925) 21; Jurisdiction of the European Commission of the Danube, PCIJ Ser. B No. 14 (1927) 36.

${ }^{97}$ Military and Paramilitary Activities in and against Nicaragua(Nicaragua v United States) (Merits) (Nicaragua case) (1986) ICJ Rep 14.

98 Customs Regime between Germany and Austria, Advisory Opinion of 5 September 1931, PCIJ Ser. A/B, No 41 (1931), 57-8 (Individual Opinion by Judge Anzilotti). 
can be derived from that commitment." 99 In other words, "States weigh the costs and benefits of their actions and proceed where benefits outweigh costs." 100

States take into account the likely cost of committing to a treaty, i.e., the extent the treaty will affect their sovereignty, and the material, economic or financial benefits from which they can get from the treaty. Malaysia's adoption of the WTO Agreements is a good example in this respect. However, when it comes to human rights treaties, "they do not offer States any obvious reciprocal benefits, as do many other treaties."101

The Rome Statute is a human right treaty. Although acceding to the Rome Statute is not so much beneficial to the country and its people from financial, economic or material point of view, it is submitted that it is the right thing to do in the interest of the humanity as a whole. In other words, it is not only for the betterment of a country or a people but for the betterment and protection of the entire human race. Malaysia's adoption of the four Geneva Conventions for the Protection of Victims of Armed Conflict, 1949 and the Genocide Convention, 1948, are similar good examples in this respect.

\section{Rome Statute Crimes: most heinous crimes of international concern}

Under international law, there are certain crimes which are so destructive of the international order and are contrary to the interests of the international community as a whole that they are treated as delicta jure gentium (international crimes). ${ }^{102}$ They are intended to protect values considered important by the whole international community and consequently bind all States and individuals. Since there is a universal interest in repressing these crimes, under international law the

${ }^{99}$ Yvonne M Dutton, "Commitment to International Human Rights Treaties: the Role of Enforcement Mechanisms," University of Pennsylvania Journal of International Law, 34:1 (2012): 1-66, at 15.

${ }^{100}$ See Andrew T. Guzman, "A Compliance-Based Theory of International Law," California Law Review, 90 (2002): 1823, at 1860.

${ }^{101}$ Oona S. Hathaway, "Why do Countries Commit to Human Rights Treaties?" The Journal of Conflict Resolution, 51:4(2007) 589-90.

${ }^{102}$ See FA Mann, "The Doctrine of Jurisdiction in International Law" (1964-I) 111 Recueil des Cours 95. 
perpetrators may be prosecuted and punished by any State, regardless of territorial or nationality link with the perpetrator or his victim. ${ }^{103}$ The purpose of conceding "universal jurisdiction" is to ensure that no such offence goes unpunished. ${ }^{104}$

According to Bassiouni, "certain international crimes rise to the status of jus cogens; these include the four Rome Statute crimes, namely: genocide, crimes against humanity, war crimes, and aggression."105 Recognizing certain international crimes as jus cogens carries with it the duty to prosecute or extradite, ${ }^{106}$ the non- applicability of statutes of limitation for such crimes, ${ }^{107}$ and universality of jurisdiction ${ }^{108}$ over such crimes irrespective of where they were committed, by whom (including Heads of State), against what category of victims, and irrespective of the context of their occurrence (peace or war). Above all, "the characterization of certain crimes as jus cogens places upon States the obligatio erga omnes not to grant impunity to the violators of such crimes." 109

103 Antonio Cassese, International Law (Oxford: Oxford University Press, 2001), 246; Antonio Cassese, International Criminal Law (Oxford: Oxford University Press, 2003), 23.

${ }^{104}$ Akehurst, $\mathrm{n} 1$ above, $\mathrm{p} 113$.

${ }^{105}$ M. Cherif Bassiouni, "International Crimes, Jus Cogens and Obligatio Erga Omnes," Law and Contemporary Problems, 59:4 (1996): 63, at 68.

${ }^{106}$ See M. Cherif Bassiouni \& Edward M. Wise, Aut Dedere Aut Judicare: the Duty to Extradite or Prosecute in International Law, (Dordrecht, Boston, London: Martinus Nijhoff Publishers, 1995).

${ }^{107}$ See Convention on the Non-Applicability of Statutory Limitations to War Crimes and Crimes Against Humanity, adopted on26 Nov, 1968 and entered into force on 11 Nov, 1970; 754 UNTS 73.

${ }^{108}$ See Kenneth Randall, "Universal Jurisdiction under International Law," Texas Law Review, 66 (1988) 785; Luc Reydams, "Universal Jurisdiction over Atrocities in Rwanda: Theory and Practice," European Journal of Crime, Criminal Law and Criminal Justice, 1 (1996): 18.

${ }^{109}$ Naomi Roht-Arriaza, "State Responsibility to Investigate and Prosecute Grave Human Rights Violations in International Law," California Law Review, 78 (1990): 449, at 475 n.137; Michael P. Scharf, "Swapping Amnesty for Peace: Was There a Duty to Prosecute International Crimes in Haiti?," Texas International Law Journal, 31( 1996): 1, at 4. 
Rome Statute crimes: a hundred times worse than crimes under domestic criminal law

Naturally it is difficult for a layman to differentiate a crime under domestic criminal law, which he is very familiar with, and an international crime. Murder and rape, for instance, appear to be most serious and cruel crimes under domestic criminal law. Simply put, murder implies killing of a man while rape is forceful sexual intercourse with a woman only. However, taking the life of a man or raping a woman, however cruel it appears, can never reach the level of severity of an international crime.

The first Rome Statute crime is 'genocide', that is, "killing of people with intent to destroy in whole or in part a national, ethical, racial or religious group." 110 The "crimes against humanity" are a wide spectrum of heinous crimes, including "murder, extermination, enslavement, torture, rape, sexual slavery, enforced prostitution, forced pregnancy," "committed as part of a widespread or systematic attack directed against any civilian population, with knowledge of the attack."111 "War crimes" are "grave breaches of the four Geneva Conventions of 1949 and other serious violations of the laws and customs applicable in international and non-international armed conflicts (normally committed during an armed conflict against protected persons such as civilians, prisoners of war, those who cannot fight any more, and so on.) ${ }^{112}$ The "crime of aggression" is "the use of armed force by a State against the sovereignty, territorial integrity or political independence of another State, or in any other manner inconsistent with the Charter of the United Nations." 113

\section{Impunity of cruel perpetrators: the right thing to do}

Out of the numerous perpetrators who are responsible for genocide, crimes against humanity and war crimes, a few remarkable names include the former Serbia President Milosevic, General Mladic and Karadzic, who were responsible for the extinction of forty thousand Bosnian Muslims with genocidal intent in the "Srebrenica massacre," and

\footnotetext{
110 The Rome Statute, Article 6.

${ }^{111}$ Ibid., Article 7.

112 Ibid., Article 8.

${ }^{113}$ Ibid., Article 8 bis.
} 
the Khmer Rouge regime under the leadership of Pol Pot, who committed the Cambodian genocide, which resulted in the deaths of approximately 1.5 to 2 million people, nearly a quarter of Cambodia's population, including the ethnic Cham Muslim minority.

The "crime of aggression" is normally committed by powerful States only and a few instances are the United States' military involvements in Afghanistan, Iraq, Libya, and Syria, Israel's use of military force against Arab territories and occupation of Palestine, and Russia's use of military force against Georgia (2008). It is therefore not surprising that these powerful States bitterly oppose the Rome Statute for fear that their leaders could be charged with the crime of aggression. This kind of crime is not necessary even to think about for a small State like Malaysia. In other words, crimes under the Rome Statute could be considered out of thought for a State with the characteristic of Malaysia.

Protecting and rendering redress to the innocent victims: the right thing to do

Victims of these heinous crimes are innocent people, civilians, those who do not take part in armed conflicts, and women and children who are the most vulnerable. As a matter of fact, the overwhelming majority of these pitiful victims of atrocity crimes are Muslims and most of the places where these crimes occur are Muslim majority States.

When considering acceding to the Rome Statute, the decisive factor is to ponder upon whether it is the right thing to do or not. This is because it is ordained in the Holy Qur'an that: "You are the best of peoples, ever raised up for mankind, enjoining what is right, forbidding what is wrong...."114 The crucial question, therefore, is: are we siding with those cruel perpetrators of atrocious crimes, who are powerful leaders, such as Milosevic, Mladic, Karadzic, and Pol Pot, or with the vulnerable victims of these crimes: Palestinians, Syrians, Libyans, Afghans, Iraqis, Sudanese, Rohingyas, and so on and so forth, who have been suffering from these atrocities for generations?

${ }^{114}$ Al- Qur'an, Surah Ali Imran, 3:110. 


\section{Rejecting the Rome Statute while Malaysia has already been a party to many other multilateral treaties that are more onerous}

Throughout its history, Malaysia has entered into hundreds of international treaties and conventions that are legally binding on Malaysia in the international sphere. According to the official list, there are two hundred and seventy seven (277) multilateral treaties to which Malaysia is a party, deposited with the Secretary-General of the United Nations. ${ }^{115}$ Some are very important and onerous treaties. The following are only a few examples:

(1) General Agreement on Trade in Goods (GATT), 1994;

(2) General Agreement on Trade in Services (GATS), 1994;

(3) Convention on the Rights of the Child, 1989.

(4) Convention on the Elimination of all Forms of Discrimination against Women, 1979;

(5) United Nations Convention on the Law of the Sea of 1982;

(6) Four Geneva Conventions for the Protection of Victims of Armed Conflict, 1949;

(7) Genocide Convention 1948;

(8) Conventions on the Privileges and Immunities of the United Nations 1946;

(9) Charter of the United Nations, 1945.

The Charter of the United Nations is the most onerous multilateral law-making treaty to which Malaysia is a party. Of the six principal organs, the Security Council is most powerful and its decisions are legally binding on all States including Malaysia. The striking examples are those resolutions of the $\mathrm{SC}$ on suppressing international terrorism, non-proliferation of weapons of mass destruction, and combating the Islamic State (IS). A small undemocratic organ with only 15 members makes decisions for all the 193 members of the UN and frankly speaking

\footnotetext{
115 Multilateral Treaties Deposited with the Secretary-General of the United Nations, Participant Malaysia, https://treaties.un.org/Pages/TreatyParticipantSearch.aspx?clang=_en, accessed 28 October 2019.
} 
they intrude so much on sovereignty of the member States. Still Malaysia is a member of the UN and no one suggests that Malaysia must withdraw from the UN Charter as it erodes Malaysian sovereignty.

In stark contrast to the UN Charter, in particular the unbridled power of the Security Council which is under the complete control of the Big Five with the privilege of veto power, the Rome Statute of the ICC is governed by the Assembly of States Parties (ASP), consisting of one representative from each State party, having an equal right of one vote. Firmly based on the democratic values, every State party has equal right and equal say in the ASP and decisions are made by consensus or failing which by a majority vote. ${ }^{116}$

The judges of the ICC are elected by the ASP by secret vote from the list of candidates nominated by States parties. Each State party may nominate one candidate. ${ }^{117}$ In relation to the qualifications of the judges, the Rome Statute provides: "The judges shall be chosen from among persons of high moral character, impartiality and integrity who possess the qualifications required in their respective States for appointment to the highest judicial offices." 118 The 'independence of the Judges' is clearly guaranteed in the Rome Statute. ${ }^{119}$ Not only the judges but the Prosecutor, who should be a person of high moral character and highly competent, is also elected by secret ballot by an absolute majority of the members of the Assembly of States Parties. ${ }^{120}$ Any State party may propose an amendment or review of the Rome Statute and it shall be determined by the ASP through consensus or failing which by a majority vote. ${ }^{121}$ All the above clearly demonstrates the fact that if Malaysia is a party to the Rome Statute, the country will be in the driver seat, together with other States parties, in the election of judges and the Prosecutor, in the "management oversight of the Presidency, the Prosecutor and the Registrar regarding the administration of the Court" 122 and in any amendment and review of the Statute.

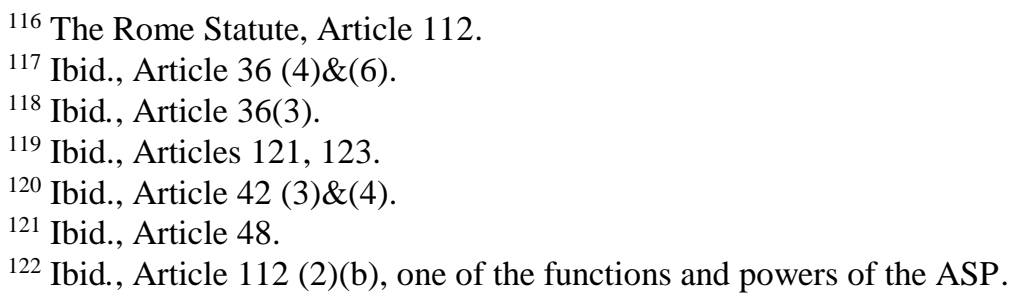




\section{Being bound by an international judicial institution: quite normal and not eroding sovereignty}

Currently Malaysia is under the purview of the three international judicial organs, namely: (i) International Tribunal for the Law of the Sea established under the UN Convention on the Law of the Sea; (ii) Dispute Settlement Body (DSB) of the World Trade Organization (WTO); and (iii) International Court of Justice as the principal judicial organ of the UN. As all these judicial bodies are established by multilateral treaties, Malaysia has already exercised its sovereign authority to be a part of them.

With respect to the first two international tribunals (ITLOS and DSB of the WTO), Malaysia is bound by their dispute settlement mechanisms. Malaysia has the right to initiate a proceeding against another State or put a defence against any proceeding by another State. In relation to the ITLOS, Malaysia initiated a proceeding against Singapore in 2003 regarding land reclamation by Singapore in the Straits of Johor. ${ }^{123}$ As far as the WTO is concerned, Malaysia, together with India, Pakistan and Thailand, initiated proceedings against the United States relating to import prohibition of certain shrimp and shrimp products in $1997 .{ }^{124}$ In 1995 Singapore made a complaint against Malaysia regarding prohibition of imports of polyethylene and polypropylene before the DSB of the WTO. Malaysia defended the case as a respondent. ${ }^{125}$ Although the responsibilities taken under these conventions are indeed onerous, no one argues that the conventions affect sovereignty of Malaysia.

Although the ICJ's jurisdiction is based on consent of the two disputing States, once consent is given, the decision of the Court is binding on the parties and compliance is the responsibility of the

${ }^{123}$ Case Concerning Land Reclamation by Singapore in and around the Straits of Johor (Malaysia v Singapore) Provisional Measures, (2003) ITLOS Case No 12.

${ }^{124}$ United States - Import Prohibition of Certain Shrimp and Shrimp Products (Complainants: India, Malaysia, Pakistan, Thailand), WT DS 58/23, 23 November 2001.

${ }^{125}$ Malaysia - prohibition of imports of polyethylene and polypropylene, (Complainant: Singapore), WT/DS1/3, 31 March, 1995. 
parties. ${ }^{126}$ Pulau Ligitan and Pulau Sipadan case ${ }^{127}$ and Pulau Batu Puteh case ${ }^{128}$ are good examples of disputes in which Malaysia and the other parties graciously complied with the decisions of the Court.

There is one argument made by those who oppose the Rome Statute to the effect that we should not allow an outside foreign judicial authority to review decisions of our own courts. Before commenting on it, first of all it is necessary to properly define "foreign judicial authority." If it is simply defined as a foreign court or a court of a foreign country, this argument is correct as no foreign court has any power to review or to affect the decisions of the Malaysia courts. However, if it is meant to include also international courts and tribunals like the ICC, with respect it is submitted that this is not the case. This argument is probably made on the basis of the confusion of the nature and standing of international courts that are operating in the international sphere and domestic courts operating in the domestic sphere (that is, operative only within the territory of a particular country).

In the domestic sphere, the Federal Court possesses the highest judicial power but its decisions are binding only within the territorial limits of Malaysia. In other words, Malaysian courts have no power at all in Indonesia and vice versa. This is the essence of the doctrine of sovereign equality of States. States are sovereign and they are equal in terms of sovereignty. That is why one sovereign State has no power at all by means of its judicial or other state organs over another sovereign State. ${ }^{129}$

However, the extent of this sovereignty stops there and does not extend to the international sphere. In the international sphere, there are international courts and tribunals and international law prevails out there. States cannot rely on its own domestic law before an international court

126 The Statute of the ICJ, Article 36(1), the Charter of the United Nations, Article 94.

127 Sovereignty over Pulau Ligitan and Pulau Sipadan (Indonesia/ Malaysia) (2002) ICJ Rep 625.

${ }^{128}$ Sovereignty over Pedra Branca/ Pulau Batu Puteh, Middle Rocks and South Ledge (Malaysia/Singapore) (2008) ICJ Rep 12.

129 The legal maxim is "Par in parem non habet imperium: An equal has no power over an equal." See Peter Malanczuk (ed), Akehurst's Modern Introduction to International Law, 7th edn (London: Routledge, 1997), 118. 
to defend a violation of international law. ${ }^{130}$ Furthermore, States normally resort to international courts when there is an alleged breach of international law, denial of justice, or when a local court fails to honour an obligation under international law. That is why international courts appear to have the power (although one cannot strictly call it as judicial review) to determine whether a decision of a domestic court or a conduct of a State organ of a particular country is in violation of international law. This is in fact the main function of international courts and tribunals.

A striking example in the Malaysian context is MBF Capital Bhd \& Anor v Dato' Param Cumaraswamy. ${ }^{131}$ This is a defamation case where Dato' Pram Cumaraswamy claimed immunity as a Special Rapporteur of the UN Human Rights Commission under the Convention on the Privileges and Immunities of the United Nations, 1946, to which Malaysia is a party. The Court rejected his claim. The Government of Malaysia and the United Nations finally agreed to refer this question to the international Court of Justice for an advisory opinion. The World Court concluded, inter alia" "that the Special Rapporteur was entitled to immunity from legal process of every kind; and that the Government of Malaysia had the obligation to inform the Malaysian courts of this finding." 132 As a result, in Insas Bhd \& Anor v Dato' Param Cumaraswamy, the High Court of Malaya ruled that "whilst the court might disagree with certain aspects of the decision of the ICJ, ... the court was bound to give legal effect to the advisory opinion." 133 This is by virtue of Article 30 of the Immunity Convention which provides that "The opinion given by the Court [ICJ] shall be accepted as decisive by the parties." In this situation, no one made an objection on the ground that Malaysia's adoption of the Convention on the Privileges and Immunities of the United Nations 1946 eroded Malaysian sovereignty or that Malaysia lost its sovereignty by referring the case to the ICJ.

\footnotetext{
${ }^{130}$ See above pp. 10-11.

131 [1997] 3 CLJ 927, High Court Malaya, Kuala Lumpur.

132 Difference Relating to Immunity from Legal Process of a Special Rapporteur of the Commission on Human Rights (1999) ICJ Reports 62.

133 [2000] 4 CLJ 709, High Court Malaya, Kuala Lumpur.
} 


\section{FINDINGS AND RECOMMENDATIONS}

The following are the major findings of the present work:

(1) In the present-day interdependent world, no State can stay alone in isolation without any relationship with other States. International law, therefore, is a necessity for all States that are members of the international community of nations. ${ }^{134}$

(2) Entering into a treaty is an attribute of State sovereignty. "Restrictions upon a State's liberty, whether arising out of a treaty or customary international law, however extensive and burdensome these obligations may be, do not as such in the least negate its sovereignty." 135

(3) By acceding to the Rome Statute or by ratifying any other treaty, Malaysia by no means loses its sovereignty. Rather, Malaysia, as a sovereign State, exercises its own sovereign right in deciding to accept the undertaking.

(4) However, most importantly, before making such a decision, Malaysia must first of all make sure that it is the right thing to accede to or ratify a particular treaty. The decisive factor in making such a decision is either it is for the benefit of the country or in the interest of the humanity as a whole, i.e., achieving the higher value that surpasses national interest. The Rome Statute falls in the second category.

The following are the recommendations to the Government and the people:

(1) When Dato' Saifuddin Abdullah signed the instrument of accession to the Rome Statute, it was completely in accordance with the Federal Constitution because treaty-making power in Malaysia is entrusted to the Executive (the Cabinet) by virtue of Articles 39, and 80(1), read together with Article 74, of the Constitution. ${ }^{136}$ There is

\footnotetext{
${ }^{134}$ This is affirmed by the legal maxim: "Ubi societas Ibi Jus" (When there is a society, there is law).

135 Customs Regime between Germany and Austria, Advisory Opinion of 5 September 1931, PCIJ Ser. A/B, No 41 (1931), 57-8 (per Judge Anzilotti).

${ }^{136}$ See for the details, Abdul Ghafur Hamid, "Treaty-Making Power in Federal States with Special Reference to the Malaysian Position," Journal of Malaysian
} 
nothing in the Federal Constitution that requires submission to Parliament or to the Conference of Rulers before ratification or accession of a treaty. Furthermore, as Foreign Minister of Malaysia, he has the authority under Article 7 of the Vienna Convention on the Law of Treaties 1969 to sign the instrument of accession.

(2) The Pakatan Harapan Government, however, acted somewhat hastily in making the decision to accede to the Rome Statute "without extensively engaging with various stake holders and the people in general." Because of that although what the Government did was in accordance with law, the Conference of Rulers, Parliament, and the people were not happy. They felt that they were neglected. It is true that the Executive (the Cabinet) exercised the sovereign power of treaty-making as delegated to them by the Federal Constitution. The question is: whose sovereignty is this? The ultimate owner of sovereignty is the people. Parliament which consists of people's representatives, reflects the will of the people. Parliament, therefore, must be able to perform the checks and balances over the Executive. That is the reason why in many other countries of the world, the Executive alone cannot make a treaty. They must get the approval of Parliament or the Legislature. The American Constitution is a good example. ${ }^{137}$ For that to happen, Malaysia needs to amend the Federal Constitution. But it will need two-thirds majority and it will take time.

(3) For the time being, what the Government needs to do is that before it decides to accede to or ratify a treaty, although it is not necessary under the law as it stands now, it should extensively engage all stake holders (Yang di Pertuan Agong, Conference of Rulers, Parliament, academia, Bar Council, relevant NGOs, and the people (grassroots). This is important as the Government will have to face similar problems in considering accession to other human rights treaties like

and Comparative Law (JMCL) 30 (2003):65-88. See also: The Government of the State of Kelantan $v$ The Government of the Federation of Malaya and Tunku Abdul Rahman Putra Al-Haj, [1963] MLJ 355.

${ }^{137}$ See the American Constitution, Article II, s 2, which provides: The President shall have power, by and with the advice and consent of the Senate, to make treaties, provided two- thirds of the Senators present concur." 
ICCPR or ICESCR. The issue of the Rome Statute may also reoccur for consideration at a time in the future.

(4) As far as the Rome Statute is concerned, gigantic steps for dissemination and educating the people would be required. This is because the ordinary people of Malaysia do not know anything about the International Criminal Court. They do not know that millions of people around the world have been victims of heinous international crimes committed by cruel and atrocious rulers, heads of States or governments, military regimes, commanders, and those who are in power. They do not know how these people in power abuse their powers in order that their own national courts can never prosecute them for their serious crimes. This is what is actually happening in several African countries, Palestine, Syria, Libya, Myanmar and so on. They do not know that this is the reason why the international community has fought a tough battle against all odds for so many years to be able to establish a permanent international criminal court so that those powerful people who committed heinous international crimes cannot go unpunished. They do not know why powerful States like the United States, Israel and Russia have bitterly opposed the Rome Statute given the fact that their armed forces are involved in armed conflicts in various parts of the world and that their leaders and commanders might be responsible for the crimes committed by their military under the doctrine of command responsibility. They do not know whether it is logical to accept the claim that kind and pious Malaysians or a Malay Ruler would ever commit such heinous crimes. They do not know that these crimes are non-existent in Malaysia at present and most probably will not occur in future in such a peaceful country resided by people with deep religious conviction and culture. Finally, they do not know that accession to the Rome Statute is not meant just for the benefit of Malaysia alone but for the achievement of the higher value of humanity as a whole and to protect victims of these crimes: the Palestinians, the Syrians, the Libyans, the Rohingyas, and potential victims around the globe.

\section{CONCLUSION}

Whenever people talk about 'sovereignty,' what they usually have in mind is that sovereignty is the supreme authority of a State above which 
there is no other higher authority and that it is absolute and unqualified and no external authority can limit the power of a sovereign State. The present paper has proven beyond reasonable doubt that this widespread misconception of sovereignty is not true anymore and that sovereign States are subjects of international law in the same way as individual human beings are subjects of national law. Since sovereign States are subjects of international law they have rights and duties under international law, they are bound by international law, and they need to comply with decisions of international courts and tribunals to which they have given their consent.

All the hot debates and arguments about the Rome Statute boil down to one factor: the general rejection of international law and international courts; the mindset that international law is an alien law or a foreign law and international courts are alien courts. In fact, a foreign law is the law of a foreign country and a foreign court is the court of a foreign country. International law is indeed not a foreign law but a law that operates in the international sphere, that is, the sphere of relations among sovereign States. Then who makes international law? Sovereign States themselves make international law by using their sovereign authority but surrendering a small portion of their sovereignty of their own free will and that is international law. Malaysia, as a sovereign State, takes part in the creation of international law, together with other countries of the world. That is why international law is not an alien law for Malaysia, but the law that Malaysia itself consents and agrees to comply with it. 